\title{
Root Development of Acerola Trees as Affected by Liming
}

\author{
E. Hernández-Medina, J. Vélez-Santiago, and M. A. Lugo-López ${ }^{1}$
}

\section{INTRODUCTION}

The possibilities of producing acerola or West Indian cherry (Malphigia punicifolia L.) in commercial orchards have been of much interest because the fruit is considered to be the richest source known of natural vitamin $\mathbf{C}$ $(1,2,7){ }^{2}$ Interest in this fruit has been high since 1946 when the first paper was published on the subject (2). Landrau, Jr. and Hernández-Medina published a paper in 1959, reporting the effects of fertilizer on acerolas grown in pots in Rio Piedras (6). Lime proved beneficial for acerola production, both in yields of fruit and in ascorbic acid. Application of the first 100 pounds of each major element did not affect additional root development significantly; however, 200 pounds of each significantly increased root volume. Liming increased root weight 70 percent in trees which received the highest rate of the major elements as compared with root weight of trees grown in unlimed soil, but which also were supplied with 200 pounds of nitrogen, phosphorus, and potassium.

This early research report was followed in 1960 by the report of Hernández-Medina and Vélez-Santiago (b). They reported on three-year production records from a field experiment in which plots were limed to raise $\mathrm{pH}$ levels from 4.5 , (original soil $\mathrm{pH}$ ) to 5.5 and 6.5 , respectively. Plant growth and development were greatly favored by liming the soil. The three-crop average for trees grown in soil limed to $\mathrm{pH} 5.5$ and 6.5, respectively, was 130 and 200 percent more fruit than the unlimed plots kept at the original $\mathrm{pH}$ level. Ascorbic acid production per acre also was enhanced with liming.

This paper reports on root volume studies conducted at the experimental orchard from where Hernández-Medina and Vélez-Santiago (5) previously reported on fruit yields.

\section{PROCEDURE}

The small acerola trees were almost 1-year old at the time of planting in the field. They were planted in an acid Mabi clay, $\mathrm{pH}$ 4.5, which occurs throughout the Island on long low gentle slopes within the humid section.

1 Agronomist, formerly Research Assistant in Horticulture and now Assistant Animal Husbandman, and Soil Scientist, respectively, Mayaguiez Campus, Agricultural Experiment Station, University of Puerto Rico, Río Piedras, P.R.

2 Italic numbers in parentheses refer to Literature Cited, p. 61. 
This soil is characterized by a grayish brown plastic heavy clay surface about 8 or 10 inches thick with good tilth when properly worked $(9)$.

Lime requirement tests were conducted (8) on all experimental plots prior to planting. Lime then was applied to the soil, except in the control plots, according to treatment differentials to raise the original soil $\mathrm{pH}$ of .4 .5 to 5.5 and 6.5 , respectively.

Plots $20 \times 20$ feet, comprising an area of approximately $1 / 100$ of an acre, were found to be most adequate for the field work. Ditches were dug around each plot to avoid any interfeeding possibilities among trees of adjacent plots.

Measures were followed to assure good pest control in this experiment as reported previously $(6)$.

The clone B-17 was selected for this investigation. It is a high yielder, unusually high in ascorbic acid content and of juice per fruit (1). The original experiment consisted of 9 foliar treatments with magnesium and minor elements given to trees grown at three $\mathrm{pH}$ levels. Each foliar treatment was replicated four times. The experiment was planted following a split plot design with subunits in a balanced lattice.

Undisturbed soil cores were taken with a 3-inch Uhland sampler at the end of three years. Cores were taken within 20 - and 40 -inch radii from the main stem from 12 selected trees in plots kept at the previously indicated $\mathrm{pH}$ levels and at depths of 0 to 6 and 6 to 12 inches. The roots were separated carefully from the soil, washed, dried in an oven at $110^{\circ} \mathrm{C}$. and weighed.

\section{RESULTS AND DISCUSSION}

Mean values for root weight obtained under each treatment are given in table 1. Mean differences are highly significant in each of the four sets of means which can be compared statistically.

Liming to $\mathrm{pH} 5.5$ in each case increased the weight of roots significantly over that obtained in the unlimed plots. Furthermore, liming to $\mathrm{pH} 6.5$ produced highly significant increases in root weight over both the unlimed plots and those limed to $\mathrm{pH}$ 5.5. As a result of this increased root development, trees can more effectively exploit a larger and deeper volume of soil which in turn allows more adequate nutrient absorption. Trees supplied with lime, thus had a greater root volume, made a thrifty growth, with dark-green foliage as compared to the rather weak growth with light green or yellow green foliage of unlimed trees (fig. 1). Lime can be beneficial in a two-fold aspect: as a source of calcium for nutrition and as an amendment to regulate the soil to improve the physical and to a certain extent the soil chemical properties. Both situations probably are at play in this case because the soil where the experiment was conducted was low in available calcium in addition to the soil conditions that a $\mathrm{pH} 4.5$ 
imply. The essentiality of calcium for root growth and plant development has been well demonstrated $(3,4,10)$.

The effect of lime on root development also was reflected in the total three-year yields of acerola fruit in tons per acre, as shown in the following

TABLE 1.-Variations in root weight for each trealment at 2 depths and $\&$ distances from the stem

\begin{tabular}{l|l|l}
\hline \multirow{2}{*}{ I.jme treatment } & \multicolumn{2}{|c}{ Weight of roots in $\mathrm{g.}$ at indicated depth } \\
\cline { 2 - 3 } & $0-6$ inch & $6-12$ inches \\
\hline
\end{tabular}

\begin{tabular}{l|r|r}
\multicolumn{3}{c}{ 20-in. dislance from stem } \\
\hline Unlimed, pH 4.5 & 5.27 & 2.64 \\
Limed to pH 5.5 & 9.60 & 4.56 \\
Limed to pH 6.5 & 12.10 & 6.60 \\
\hline
\end{tabular}

40-in. distance from stem

\begin{tabular}{l|l|l}
\hline Unlimed, pH 4.5 & 3.95 & 1.61 \\
Limed to pH 5.5 & 5.24 & 2.15 \\
Limed to pH 6.5 & 6.15 & 2.54 \\
\hline
\end{tabular}

L.S.D. for 20 -inch distance means at 5 percent level at 1 percent level

L.S.D. for 40-inch distance means at 5 percent level at 1 percent level

tabulation adapted from Hernández-Medina and Vélez-Santiago (5):

$\begin{array}{lc} & \text { Tons } \\ \text { Unlimed pH 4.5 } & 14 \\ \text { Limed to pH 5.5 } & 33 \\ \text { Limed to pH 6.5 } & 42\end{array}$

These yields were calculated on the basis of 218 trees per acre.

\section{SUMMARY}

Data are presented herein on the effect of liming on root development of acerola trees planted in an acid Mabi clay. Lime was applied to the soil to raise the original soil $\mathrm{pH}$ of 4.5 to 5.5 and 6.5 , respectively. After three crop years, undisturbed soil cores were taken within 20 - and 40 -inch radii from the main stem and at depths of 0 to 6 and 6 to 12 inches from selected trees in unlimed and limed plots.

Liming the soil to $\mathrm{pH} 5.5$ and 6.5, respectively, increased the amount of roots of the acerola trees significantly over that obtained in unlimed plots. 

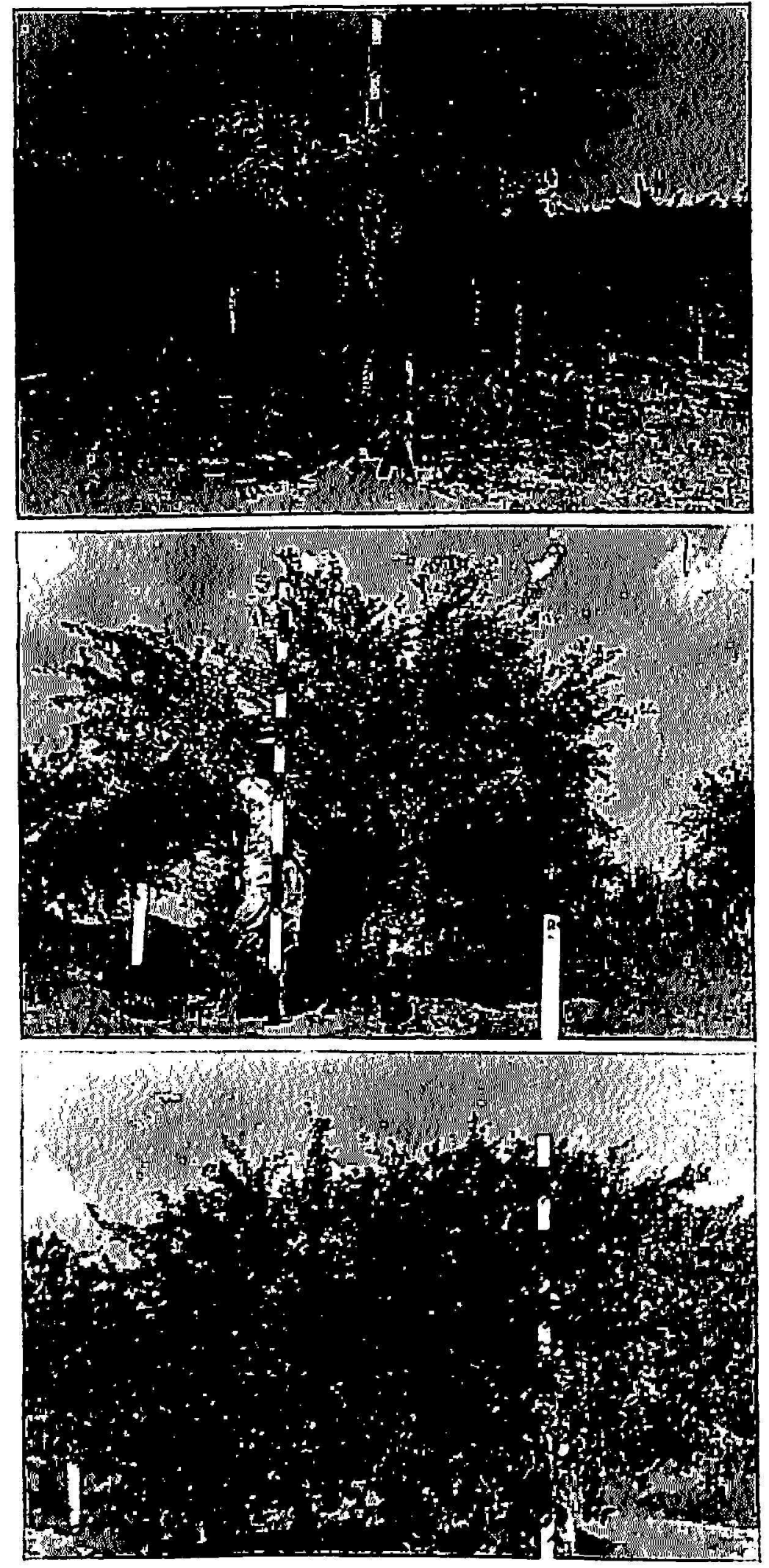

Fig. 1-A, Acerola tree not supplied with lime which made a rather weak growth with light green or yellow green foliage. $\mathrm{B}$ and $\mathrm{C}$, Trees limed to raise the original soil $\mathrm{pH}$ of 4.5 to 5.5 and 6.5 , respectively. Trees had a luxuriant vegetative growth with dark green foliage. 
The lime-treated trees developed vigorously with dark green foliage and produced significantly heavier fruit yields than the unlimed trees which made an unthrifty growth with light green or yellow-green foliage. These results point to the need for liming low calcium acid soils for successful acerola production.

\section{RESUMEN}

Se informan datos experimentales sobre el efecto de la cal en el desarrollo de las raíces del acerolo. Los arbustos se sembraron en un suelo ácido Mabí arcilloso. El suelo se encaló para subir su pH original de 4.5 a 5.5 y 6.5 , respectivamente. Después de la tercera cosecha, se tomaron columnas de suelo sin alterar, a distancias de 20 y 40 pulgadas alrededor del tronco y a profundidades de 0 a 6 y 6 a 12 pulgadas de los arbustos seleccionados en los distintos tratamientos con cal.

Los arbolitos sembrados en los suelos encalados a un pH de 5.5 y 6.5, respectivamente, tenían significativamente más raíces que los sembrados en el suelo sin encalar. Estos arbustos crecieron en forma vigorosa, con un follaje verde obscuro, y el rendimiento por acre fue significativamente superior al de los que no recibieron cal y cuyo desarrollo vegetativo fue lento y su follaje verde pálido o verde amarillento. Los resultados obtenidos indican que la práctica de encarlar los suelos ácidos y bajos en calcio es unuy recomendable en el cultivo del acerolo.

\section{LITERATURE CITED}

1. Aróstegui, F., Asenjo, C. F., Muriz, A. I., and Alemañy, L., Observations and data on a promising selection of the West Indian Cherry, Malpighia punicifolia, (L.), J. Agr. Univ. P.R. $s 9$ (3): 51-6, 1955.

2. Asenjo, C. F., and Freire de Guzmán, S. R., The high ascorbic acid content of the West Indian Cherry, Sci. 108: 219, 1946.

3. Haynes, J. L., and Robbins, W. Rei, Calcium and boron as essential factors in the root environment, J. Amer. Soc. Agron. 40 (9): 795-803, 1948.

4. Hernández-Medina, E., and Shive, J. W., Calcium-boron relationships in the nutrition of corn and the distribution of these elements in the plant, J. Agr. Univ. P.R. 30 (4): 251-91, 1946.

5. - -, and Vélez-Santiago, J., Response of the acerola (Malpighia punicifolia, L.) to the application of lime and foliar sprays of magnesium and minor elements, Proc. Amer. Soc. Hort. Sci. (Caribbean Region) 4: 20-5, 1960.

6. Landrau, Jr., P., and Hernández-Medina, E., Effects of major and minor elements, lime and soil amendments on the yield and ascorbic acid content of acerola (Malpighia punicifolia, L.), J. Agr. Univ. P.R. 49 (1): 19-33, 1959.

7. Moscoso, C. G., West Indian Cherry-richest known source of natural vitamin C, Econ. Bot. 10 (3): 280-94, 1956.

8. Riera, A., Laboratory recommendations of lime to an acid soil checks with expected pH changes, J. Agr. Univ. P.R. 30 (3): 184-5, 1946.

9. Roberts, R. C., Soil survey of Puerto Rico, USDA in cooperation with the Univ. P.R., Agr. Expt. Sta., Series 1936, (8), 1942.

10. True, R. H., The significance of ealcium for higher green plants, Sci., 55: 1-6, 1922. 